\title{
DIVERSITY OF TEA ENDOPHYTIC FUNGI: CULTIVAR- AND TISSUE PREFERENCES
}

\author{
WiN, P. M. ${ }^{1,2}-$ MATSUMURA, E. ${ }^{1,3}-$ FUKUDA, K. ${ }^{1,3^{*}}$ \\ ${ }^{I}$ Department of Natural Environmental Studies, Graduate School of Frontier Sciences, \\ The University of Tokyo, 5-1-5 Kashiwa-no-ha, Kashiwa, Chiba 277-8563, Japan \\ ${ }^{2}$ Department of Plant Pathology, Yezin Agricultural University, \\ Yezin, Nay Pyi Taw, Myanmar \\ ${ }^{3}$ Department of Forest Science, Graduate School of Agriculture and Life Sciences, The \\ University of Tokyo, 1-1-1 Yayoi, Bunkyo-ku, Tokyo 113-8657, Japan \\ *Corresponding author \\ e-mail: fukuda@fr.a.u-tokyo.ac.jp; phone: +81-3-5841-5209; fax: +81-3-5841-7554 \\ (Received 23 $3^{\text {rd }}$ Aug 2017; accepted $18^{\text {th }}$ Dec 2017)
}

\begin{abstract}
Endophytic fungi were isolated from four healthy tissues (new leaf, old leaf, bark, and xylem) of three Japanese tea cultivars (Hokumei, Sayamakaori, and Yabukita) at the Saitama Tea Research Institute, Japan in July 2015. A total of 520 isolates was obtained from 600 segments and were classified into 44 fungal taxa; the majority (93.2\%) belonged to the phylum Ascomycota. The lowest infection rate was found in the xylem tissue of all cultivars. The total infection rate did not differ significantly among the cultivars. Colletotrichum gloeosporioides $\mathrm{f}$. sp. camelliae and Pleosporales sp. were the predominant endophytes in all tissue types and cultivars. Most of the dominant endophytes showed obvious cultivar and tissue preferences. Tissue type played a more important role in shaping community structure than did cultivar. Colletotrichum gloeosporioides f. sp. camelliae preferred bark and old leaf tissue while Pleosporales sp. preferred new leaf tissue. The colonization frequency of C. gloeosporioides f. sp. camelliae was significantly lower in the Yabukita cultivar. Stem tissues harbored more diverse endophytes than did leaf tissues.
\end{abstract}

Keywords: fungal community, healthy tissues, Japanese tea cultivars, leaf, stem

\section{Introduction}

Endophytic fungi are mycosymbionts that colonize the internal tissues of plants without causing damage (Petrini, 1991). They are diverse, ubiquitous, and can be isolated from flora worldwide, from flowerless plants such as mosses (Davey and Currah, 2006) to urban forest trees (Matsumura and Fukuda, 2013). These fungi can improve plant survival under adverse environmental conditions (Cheplick et al., 2000). Endophytes have been a focus of research as substitutes for agrochemicals (Rabha et al., 2014; Nath et al., 2015).

Endophytic fungal composition and diversity can be affected by several factors like host species or cultivars, location, soil types, plant physiological status, seasons, geographic coordinates and tissues or organs of the host plants (Arnold and Lutzoni, 2007; Tian et al., 2004; Naik et al., 2009). Campisano et al. (2014) studied endophytic fungal composition in grapevines cultivated using organic production and Integrated Pest Management (IPM). They observed Mesorhizobium, Caulobacter and Staphylococcus genera as dominant endophytes in organic vineyards, while Ralstonia, Burkholderia and Stenotrophomonas were more abundant in grapevines from IPM vineyards. 
Tea (Camellia sinensis) is the most popular drink in the world. In the recent decades, endophytes gain attention from many researchers to be used as the substitutes for agrochemicals in the sustainable tea production (Rabha et al., 2014; Nath et al., 2015). Because of their benefits, there should be a better understanding of tea endophytes. To use endophytes for agricultural application, many researchers are trying to discover new stains. Studying their diversity, distribution and colonization pattern can give basic information for further advance studies for the commercial use of ecofriendly biofertilizers and biocontrol agents in sustainable tea production. In accordance with Fang et al. (2013), the systematic study of tea endophytes was started in the beginning of the 21 st century. Therefore, research about tea endophytes is still limited if compared to any other economically important crops.

According to Yagi et al. (2010), 52 tea cultivars are registered with the Japan Ministry of Agriculture, Forestry, and Fisheries. Despite the importance of the crop, the diversity of endophytic fungi of Japanese tea cultivars remains unexplored. According to Osono (2014), 45 papers related to phyllosphere fungi, including endophytes and epiphytes, in Japan were published from 1990 to 2013; most focused on forest trees. Few endophytic studies of agricultural crops, including tea plants, have been performed in Japan. Use of endophytic fungi of tea plants as substitutes for agrochemicals in sustainable tea production requires an enhanced understanding of tea endophytes. Studying their diversity, distribution, and colonization of different tissues and cultivars would provide basic information for commercial application of endophytes in the industrial, pharmaceutical, and agricultural sectors. This study aimed to elucidate the species composition and tissue and cultivar preferences of endophytic fungi isolated from three Japanese tea cultivars.

\section{Materials and Methods}

\section{Study plant}

Tea (Camellia sinensis) was discovered about around 2700BC and so it can be assumed that it is one of the oldest beverages in the world (Chang, 2015). Numerous pathogens including fungi, bacteria and virus can attack tea plants and lead to serious crop losses. In Assam, India, about 14-50 \% of crop loss is caused by pests and diseases. Among the diseases, grey blight and brown blight caused by Pestalotiopsis theae and Colletotrichum camelliae, respectively, are the most destructive and economically important ones (Rabha et al., 2013). Keith et al. (2006) described that blister blight, horse-hair blight, and twig dieback/stem canker are very serious diseases in major tea-producing area of the world. Crane and Balerdi (2013) listed blister blight (Exobasidium vexans), net blister blight (E. reticulum), anthracnose (Colletotrichum theasinensis), and red rust (Cephaleuros parasiticus) as tea plant pathogens. According to these authors, we can easily realize that tea plants are threatened by several different pathogens. Moreover, new diseases which can cause economic losses in various crops emerge recurrently due to the drastic changes in temperature and precipitation pattern. Various chemical pesticides (insecticides and fungicides) containing different chemical compounds with different mode of actions are now being used by tea growers to control tea diseases. These chemical residues could cause harmful effects to plants, human beings, environment and biodiversity including endophytes. 


\section{Sample collection}

Plant samples were collected in July 2015 from the Saitama Tea Research Institute

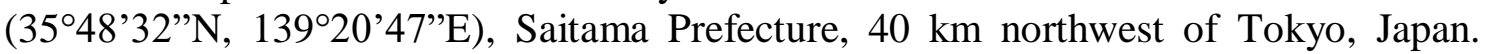
Branches bearing four tissue types (new leaf, old leaf, bark and xylem of the stem) were cut from three cultivars; Hokumei, Sayamakaori, and Yabukita (Table 1). New and old leaf tissues were on average 1 month and 1 year old, respectively. All cultivars were grown in lines in the same plot; each line was $50 \mathrm{~m}$ long and $1 \mathrm{~m}$ wide. One branch per $2 \mathrm{~m}$ was cut from two lines of each cultivar. From each branch, five segments of each tissue type (Fig. 1) were used. A total of 600 segments ( 3 cultivars $\times 4$ tissues $\times 2$ lines $\times 5$ branches $\times 5$ segments $=600$ segments) were used for isolation of endophytic fungi.

Table 1. Characteristics of the tested cultivars

\begin{tabular}{|c|c|c|c|}
\hline & Yabukita $^{* 1}$ & Sayamakaori $^{* 2}$ & Hokumei $^{* 3}$ \\
\hline Year registered & 1953 & 1971 & 1992 \\
\hline $\begin{array}{l}\text { Cultivar } \\
\text { number }\end{array}$ & 6 & 31 & 43 \\
\hline Parents & $\begin{array}{c}\text { Native Shizuoka } \\
\text { species }\end{array}$ & 'Yabukita' plants & 'Sayamakaori' x 5507 \\
\hline Leaf & $\begin{array}{l}\text { Oval, long, straight } \\
\text { and intensely green }\end{array}$ & $\begin{array}{l}\text { Oval, bigger and } \\
\text { thicker than } \\
\text { 'Yabukita' }\end{array}$ & $\begin{array}{l}\text { Oval, bigger and thicker than } \\
\text { 'Yabukita' }\end{array}$ \\
\hline Harvest time & April - mid May & $\begin{array}{l}2 \text { to } 3 \text { days earlier } \\
\text { than 'Yabukita' }\end{array}$ & $\begin{array}{l}3 \text { to } 5 \text { days later than } \\
\text { 'Yabukita' }\end{array}$ \\
\hline Vigor & High & High & $\begin{array}{l}\text { More vigorous than } \\
\text { 'Yabukita' }\end{array}$ \\
\hline Yield & High & $\begin{array}{l}\text { Higher than } \\
\text { 'Yabukita' }\end{array}$ & Same as 'Sayamakaori' \\
\hline $\begin{array}{l}\text { Disease } \\
\text { resistance }\end{array}$ & $\begin{array}{c}\text { Susceptible to } \\
\text { anthracnose and gray } \\
\text { blight }\end{array}$ & $\begin{array}{l}\text { Susceptible to } \\
\text { anthracnose, slightly } \\
\text { more resistant to gray } \\
\text { blight than 'Yabukita' }\end{array}$ & $\begin{array}{l}\text { Highly resistant to } \\
\text { anthracnose, susceptible to } \\
\text { gray blight }\end{array}$ \\
\hline
\end{tabular}

Note: *1 Yagi et al. (2010); *2 Caidedo (2016) http://www.myjapanesegreentea.com/sayamakaori; *3 Caidedo (2016) http://www.myjapanesegreentea.com/hokumei

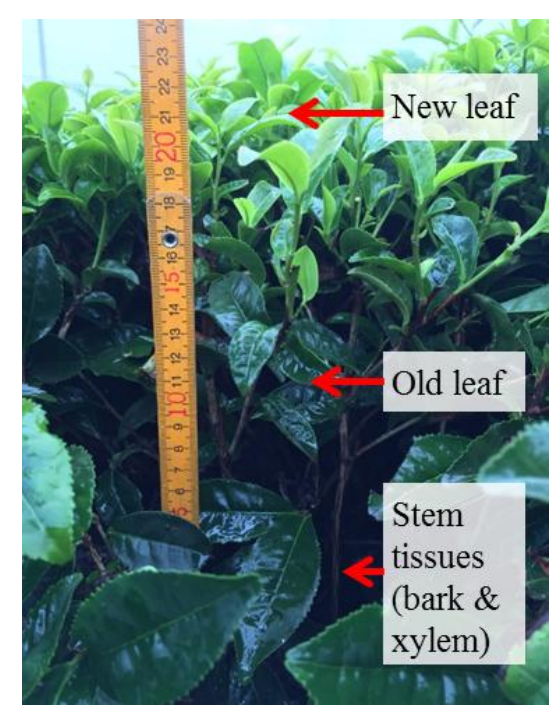

Figure 1. Tissue types used for isolation of endophytic fungi 


\section{Isolation and identification of endophytic fungi}

After collection, the plant materials were placed in clean polythene bags, labeled, and transported to the laboratory. Isolation from health tissues was carried out within $24 \mathrm{~h}$. Surface sterilization and isolation were conducted as described by Matsumura and Fukuda (2013). First, the collected plant materials were placed under running tap water for $\sim 12 \mathrm{~h}$. Surface sterilization was performed by immersing the plant materials in $80 \%$ ethanol for $1 \mathrm{~min}, 1 \%$ sodium hypochlorite for $1 \mathrm{~min}$, and $80 \%$ ethanol for $1 \mathrm{~min}$. The disinfected materials were washed twice in sterilized distilled water for $1 \mathrm{~min}$, and allowed to dry on sterilized blotting paper. For leaf tissues, 6-mm-diameter discs were removed using a sterilized cork borer. Stem tissues were debarked to separate bark and xylem using a sterilized razor blade and cut into $3 \mathrm{~mm}^{2}$ segments. These segments were placed on half-strength potato dextrose agar (1/2 PDA) medium containing chloramphenicol $(600 \mathrm{mg} / \mathrm{L})$ in 9-cm-diameter plastic Petri dishes (five discs per Petri dish). The Petri dishes were incubated at $20^{\circ} \mathrm{C}$ in the dark for 1 week. Each fungal isolate was subcultured on PDA medium in $6 \mathrm{~cm}$ Petri dishes for 5 days and identified by morphological and molecular analyses. For morphological analysis, colony color, texture, shape, size, conidia, and mycelia color were evaluated. Fungal isolates with the same morphological characteristics were placed in the same group, and $>50 \%$ of the isolates underwent molecular identification.

\section{DNA extraction and PCR amplification}

DNA extraction was conducted according to Izumitsu et al. (2012). Mycelia (0.1$1 \mu \mathrm{g}$ ) were collected from the growing edges of 4-6-day-old cultures using sterilized toothpicks and dissolved in $100 \mu \mathrm{L}$ TE buffer in a $1.5 \mathrm{~mL}$ tube. The tubes were microwaved at $600 \mathrm{~W}$ for $1 \mathrm{~min}$, stored at room temperature for $30 \mathrm{~s}$, microwaved for 1 min, and immediately cooled at $-30^{\circ} \mathrm{C}$ for at least $10 \mathrm{~min}$. Samples were finally centrifuged at 10,000 rpm for $5 \mathrm{~min}$.

The internal transcribed spacer (ITS) region of the rDNA (ITS 1-5.8S rDNA-ITS2) of each isolate was amplified using the forward primer ITS5 (5'-GGAAGTAAAAGTCGTAACAAGG-3') and the reverse primer ITS4 (5'-TCCTCCGCTTATTG ATATGC-3') according to White et al. (1990). The reaction mixture comprised $8 \mu \mathrm{L}$ sterilized Milli Q distilled water, $0.2 \mu \mathrm{L}$ of each of the $20 \mathrm{M}$ forward and reverse primers, $10 \mu \mathrm{L}$ of $2 \times$ GoTaq Master Mix (Promega) and $1.6 \mu \mathrm{L}$ of fungal DNA template. PCR was carried out in a reaction volume of $20 \mu \mathrm{L}$ in $0.2 \mathrm{~mL}$ tubes in a thermocycler. The reaction began with initialization for $10 \mathrm{~min}$ at $94^{\circ} \mathrm{C}$, then 30 cycles of initial denaturation at $94^{\circ} \mathrm{C}$ for $30 \mathrm{~s}$, annealing at $51^{\circ} \mathrm{C}$ for $1 \mathrm{~min}$, and extension at $72^{\circ} \mathrm{C}$ for $1 \mathrm{~min}$, followed by a final extension at $72^{\circ} \mathrm{C}$ for $10 \mathrm{~min}$.

Sequencing was conducted using a 3130 Genetic Analyzer (Applied Biosystems). Nucleotide sequence alignment was performed using Molecular Evolutionary Genetics Analysis (MEGA) software version 6. Isolates with $>97 \%$ similarity were identified as the same species. Sequence data were submitted to the DNA Data Bank of Japan (DDBJ) under the accession numbers LC168755-LC168797.

\section{Data analysis}

To determine the cultivar and tissue preferences of tea endophytic fungi, the infection rate (IR), colonization frequency $(\mathrm{CF})$, and relative dominance (RD) were calculated according to Fang et al. (2013) and Nalini et al. (2014): 


$$
\begin{gathered}
I R=\frac{\text { Number of tissuesegments colonizedby fung } i}{\text { Total number of tissuesegments used for isolation }} \times 100 \\
C F=\frac{\text { Number of tissuesegments colonizedby a fungalspecies }}{\text { Total number of tissuesegments used for isolation }} \times 100 \\
R D=\frac{C F \text { \% of each fungalspecies }}{\text { Total number of fungalisolates }} \times 100
\end{gathered}
$$

IR and CF were subjected to two-way analysis of variance (ANOVA) with cultivar and tissue type as factors, but no significant interaction between cultivars and tissues was detected. The CFs of the four most common endophytes (RD > 7\%) were analyzed statistically using the Tukey-Kramer honest significant difference (HSD) test to compare mean values with JMP Pro version 12.2 at the $\alpha=0.05$ level.

The Shannon-Wiener diversity index (H') and evenness index (E5) were used to analyze the diversity of the endophytic fungal community (Ludwig and Reynolds, 1988).

$$
\begin{gathered}
H^{\prime}=-\sum R D_{i}\left(\log _{e}\left(R D_{i}\right)\right) \\
\lambda=\sum R D_{i}{ }^{2} \\
E 5=\left(\frac{1}{\lambda}-1\right) /\left(e^{H^{\prime}}-1\right)
\end{gathered}
$$

Rarefaction curves were calculated to compare species richness among the tissue types and cultivars using EstimateS9 software.

A permutational multivariate analysis of variance (PERMANOVA) was used to determine the effects of cultivar and tissue type on endophytic fungal community structure using the vegan package in the $\mathrm{R}$ console. Non-metric multidimensional scaling (NMDS) ordinations were used to visualize the similarities of the endophytic fungal community among the cultivars and tissues.

\section{Results}

\section{Infection rate}

Fifty segments of each tissue type and 200 segments of each cultivar were used to isolate endophytic fungi. The IR differed significantly among the tissue types (Fig. 2A). The IRs of bark and old leaf tissues were $100 \%$ in all cultivars. New leaf tissues showed a significantly lower IR than old leaf tissues and a higher IR than xylem tissues. The lowest IR among the tissues (46, 42, and 30\% in Sayamakaori, Hokumei, and Yabukita, respectively) was in the xylem (Tables 2, 3; Fig. 2A). IRs did not differ significantly among the cultivars (Fig. 2B). 
Table 2. Colonization frequency $(C F \%)$, relative dominance ( $R D \%)$, Shannon-Wiener diversity index $\left(H^{\prime}\right)$, and evenness $($ E5) values of endophytic fungi isolated from different tissues of tea cultivars ( $H=$ Hokumei, $S=$ Sayamakaori, $Y=$ Yabukita), July 2015

\begin{tabular}{|c|c|c|c|c|c|c|c|c|c|c|c|c|c|c|}
\hline \multirow{3}{*}{ Phylum / Order } & \multirow{3}{*}{ Endophytic fungal species } & \multicolumn{12}{|c|}{ Colonization frequency \% (CF \%) } & \multirow{3}{*}{ RD \% } \\
\hline & & \multicolumn{3}{|c|}{ Bark } & \multicolumn{3}{|c|}{ Xylem } & \multicolumn{3}{|c|}{ New leaf } & \multicolumn{3}{|c|}{ Old leaf } & \\
\hline & & $\mathbf{H}$ & $\mathbf{S}$ & $\mathbf{Y}$ & $\mathbf{H}$ & $\mathbf{S}$ & $\mathbf{Y}$ & $\mathbf{H}$ & $\mathbf{S}$ & $\mathbf{Y}$ & $\mathbf{H}$ & $\mathbf{S}$ & $\mathbf{Y}$ & \\
\hline \multicolumn{15}{|l|}{ Ascomycota } \\
\hline & Colletotrichum gloeosporioides & & & & & & & & & & & & & \\
\hline Glomerellales & f. sp. camelliae & 50 & 62 & 22 & 2 & 8 & 2 & 20 & 16 & 6 & 72 & 60 & 48 & 70.8 \\
\hline Pleosporales & Pleosporales sp. & 8 & 8 & 14 & 12 & 14 & 8 & 48 & 38 & 44 & 20 & 32 & 26 & 52.3 \\
\hline Pleosporales & Peyronellaea glomerata & 2 & 14 & 4 & & 8 & 2 & 2 & 10 & 12 & & 10 & 2 & 12.7 \\
\hline Botryosphaeriales & Botryosphaeria dothidea & & & 24 & 6 & & & & & & 2 & & 2 & 7.7 \\
\hline Capnodiales & Cladosporium asperulatum & & & 2 & 6 & 2 & 10 & 6 & 2 & 4 & & & 4 & 6.9 \\
\hline Diaporthales & Diaporthe eres & & 10 & 12 & & & 2 & & 4 & & & & 2 & 6.2 \\
\hline Pleosporales & Alternaria mali & 4 & 2 & 8 & & & & 10 & 2 & 4 & & & & 5.8 \\
\hline Botryosphaeriales & Guignardia mangiferae & & & & & & & 2 & 2 & 2 & & 2 & 10 & 3.5 \\
\hline Pleosporales & Setophoma chromolaena & & & & & & & 4 & 2 & 10 & & 2 & & 3.5 \\
\hline Diaporthales & Diaporthe nobilis & 4 & & 2 & & 2 & & & 2 & 4 & & & & 2.7 \\
\hline Diaporthales & Phomopsis sp. c1 & 4 & 6 & & & & & & 2 & & 2 & & & 2.7 \\
\hline Diaporthales & Diaporthe sp. c1 & 4 & & & 2 & 2 & & & & 4 & & & & 2.3 \\
\hline Diaporthales & Phomopsis sp.c2 & 4 & & 6 & & & & & & & & & & 1.9 \\
\hline Hypocreales & Acremonium strictum & & & & 2 & & 2 & 2 & 2 & & & & & 1.5 \\
\hline Glomerellales & Glomerella sp. & 2 & 2 & & 2 & & 2 & & & & & & & 1.5 \\
\hline Diaporthales & Phomopsis sp. c3 & & 4 & 4 & & & & & & & & & & 1.5 \\
\hline Xylariales & Pestalotiopsiaaaas sp. & & & 6 & & 2 & & & & & & & & 1.5 \\
\hline Diaporthales & Phomopsis sp.c4 & 4 & & & & & & & & & & & & 0.8 \\
\hline Diaporthales & Phomopsis sp.c5 & 2 & & & & & & & & 2 & & & & 0.8 \\
\hline Incerti ordinis & Dothideomycetes sp. & & & & 2 & 2 & & & & & & & & 0.8 \\
\hline Pleosporales & Epicoccum nigrum & 2 & & 2 & & & & & & & & & & 0.8 \\
\hline Pleosporales & Paraphaeosphaeria neglecta & & & & & 4 & & & & & & & & 0.8 \\
\hline
\end{tabular}


Xylariales

Xylariales

Xylariales

Diaporthales

Diaporthales

Diaporthales

Diaporthales

Diaporthales

Diaporthales

Diaporthales

Diaporthales

Pleosporales

Pleosporales

Sordariales

Pleosporales

Capnodiales

Pleosporales

Hypocreales

Incertae sedis

Basidiomycota

Incerti ordinis

Russulales
Pestalotiopsis camelliae

Nemania sp.

Xylariales sp.

Diaporthe pustulata

Diaporthe sackstonii

Diaporthe sp. c2

Phomopsis amygdali

Phomopsis sp. c6

Phomopsis subordinaria

Phomopsis sp. c7

Melanconiella sp.

Microdiplodia hawaiiensis

Phoma herbarum

Phialemonium

dimorphosporum

Plenodomus sp.

Pseudocercospora sp.

Stagonosporopsis

cucurbitacearum

Trichoderma koningiopsis

Fungal endophyte sp.
Uncultured Basidiomycota sp.

Peniophora incarnata

Total number of species

Total number of isolates

Infection Rate (\%)

E5

$H^{\prime}$
2

2

2

2

2

2

2

2

2

2

2

\begin{tabular}{rrrrrrrrrrrrr} 
& & & & & & & 6 & 2 & & 2 & 2 & 2.3 \\
15 & 9 & 17 & 12 & 10 & 8 & 9 & 15 & 13 & 5 & 7 & 10 & 44 \\
50 & 55 & 58 & 21 & 23 & 15 & 48 & 47 & 49 & 49 & 55 & 50 & 520 \\
100 & 100 & 100 & 94 & 94 & 98 & 100 & 100 & 100 & 42 & 46 & 30 & \\
0.43 & 0.53 & 0.67 & 0.71 & 0.8 & 0.7 & 0.61 & 0.58 & 0.54 & 0.6 & 0.64 & 0.61 & \\
1.98 & 1.51 & 2.48 & 2.27 & 1.96 & 1.85 & 1.53 & 2.01 & 1.93 & 0.79 & 1.23 & 1.54 & \\
\hline
\end{tabular}


Table 3. Blast search results

\begin{tabular}{|c|c|c|c|c|}
\hline Fungal species & $\begin{array}{l}\text { Accession } \\
\text { number }\end{array}$ & BLAST search result & $\begin{array}{l}\text { Accession } \\
\text { number }\end{array}$ & Score $(\%)$ \\
\hline $\begin{array}{l}\text { Colletotrichum gloeosporioides f. sp. } \\
\text { camelliae }\end{array}$ & LC168755 & Colletotrichum gloeosporioides f. sp. camelliae & KP635401 & $557 / 559(99 \%)$ \\
\hline Pleosporales sp. & LC168756 & Pleosporales sp. LH70 & $\underline{\mathrm{HQ} 832808}$ & $570 / 576(99 \%)$ \\
\hline Peyronellaea glomerata & LC168757 & Peyronellaea glomerate & $\underline{\text { FJ481024 }}$ & $525 / 527(99 \%)$ \\
\hline Botryosphaeria dothidea & LC168758 & Botryosphaeria dothidea & $\underline{\text { KJ801792 }}$ & $568 / 572(99 \%)$ \\
\hline Cladosporium asperulatum & LC168797 & Cladosporium asperulatum & $\underline{\mathrm{LN} 834357}$ & $518 / 518(100 \%)$ \\
\hline Diaporthe eres & LC168760 & Diaporthe eres & $\underline{\text { FJ478132 }}$ & $559 / 566(99 \%)$ \\
\hline Alternaria mali & LC168759 & Alternaria mali & $\underline{\mathrm{AF} 314575}$ & $554 / 555(99 \%)$ \\
\hline Guignardia mangiferae & LC168761 & Guignardia mangiferae & $\underline{\text { KF381072 }}$ & $616 / 618(99 \%)$ \\
\hline Setophoma chromolaena & LC168762 & Setophoma chromolaena & $\underline{\text { KR093876 }}$ & $541 / 544(99 \%)$ \\
\hline Diaporthe nobilis & LC168763 & Diaporthe nobilis & $\underline{\text { KJ609006 }}$ & $552 / 555(99 \%)$ \\
\hline Phomopsis sp. c1 & LC168765 & Phomopsis sp. LH223 & $\underline{\mathrm{HQ} 832822}$ & $557 / 576(97 \%)$ \\
\hline Diaporthe sp. c1 & LC168766 & Diaporthe sp. M96 & $\underline{\mathrm{LC} 041048}$ & $528 / 542(97 \%)$ \\
\hline Phomopsis sp. c2 & LC168768 & Phomopsis sp. EF06 & $\underline{\mathrm{JQ809664}}$ & $558 / 562(99 \%)$ \\
\hline Acremonium strictum & LC168769 & Acremonium strictum & $\underline{\text { GU219464 }}$ & $558 / 562(99 \%)$ \\
\hline Glomerella sp. & LC168770 & Glomerella sp. JD08-18 & $\underline{\mathrm{JQ} 809667}$ & $534 / 536(99 \%)$ \\
\hline Phomopsis sp. c3 & LC168771 & Phomopsis sp. BFM-L44 & $\underline{\mathrm{AB} 369483}$ & $541 / 549(99 \%)$ \\
\hline Pestalotiopsis sp. & LC168772 & Pestalotiopsis sp. $1 \mathrm{MJ}-2014 \mathrm{i}$ & $\underline{\text { KJ572189 }}$ & $513 / 515(99 \%)$ \\
\hline Phomopsis sp. c4 & LC168775 & Phomopsis sp. 687 & $\underline{\text { KC662228 }}$ & $544 / 550(99 \%)$ \\
\hline Phomopsis sp. c5 & LC168773 & Phomopsis sp. 129SD/L & $\underline{\text { GU066691 }}$ & $553 / 558(99 \%)$ \\
\hline Dothideomycetes sp. & LC168774 & Dothideomycetes sp. Z4 & $\underline{\mathrm{JN} 198394}$ & $536 / 543(99 \%)$ \\
\hline Epicoccum nigrum & LC168776 & Epicoccum cf. nigrum & JQ676202 & $528 / 532(99 \%)$ \\
\hline
\end{tabular}


Paraphaeosphaeria neglecta

Pestalotiopsis camelliae

Nemania sp.

Xylariales sp.

Diaporthe pustulata

Diaporthe sackstonii

Diaporthe sp. c2

Phomopsis amygdali

Phomopsis sp. c6

Phomopsis subordinaria

Phomopsis sp. c7

Melanconiella sp.

Microdiplodia hawaiiensis

Phoma herbarum

Phialemonium dimorphosporum

Plenodomus sp.

Pseudocercospora sp.

Stagonosporopsis cucurbitacearum

Trichoderma koningiopsis

Fungal endophyte sp.

Uncultured Basidiomycota sp.

Peniophora incarnata

\begin{tabular}{|c|c|c|c|}
\hline LC168777 & Paraphaeosphaeria neglecta & $\underline{\mathrm{JX}} 496038$ & 401/407(99\%) \\
\hline LC168778 & Pestalotiopsis camelliae & $\underline{\text { KM199336 }}$ & $567 / 569(99 \%)$ \\
\hline LC168780 & Nemania sp. AK-1 & $\underline{\text { GQ906959 }}$ & $561 / 570(98 \%)$ \\
\hline LC168779 & Xylariales 10A_co2 & $\underline{\mathrm{KC} 181931}$ & $592 / 600(99 \%)$ \\
\hline LC168781 & Diaporthe pustulata & $\underline{\mathrm{KC} 343186}$ & $529 / 547(97 \%)$ \\
\hline LC168782 & Diaporthe sackstonii & $\underline{\text { KJ197287 }}$ & $511 / 521(98 \%)$ \\
\hline LC168783 & Diaporthe sp. 3 PRJ-2013 & $\underline{\mathrm{KC} 145882}$ & $542 / 551(98 \%)$ \\
\hline LC168784 & Phomopsis amygdali & $\underline{\mathrm{AF} 102998}$ & $565 / 566(99 \%)$ \\
\hline LC168764 & Phomopsis longicolla & $\underline{\text { FJ755236 }}$ & $493 / 535(92 \%)$ \\
\hline LC168785 & Phomopsis subordinaria & $\underline{\text { GQ922519 }}$ & $555 / 560(99 \%)$ \\
\hline LC168786 & Phomopsis vaccinia & $\underline{\text { KJ739493 }}$ & $502 / 565(89 \%)$ \\
\hline LC168788 & Melanconiella meridionalis & JQ926293 & $337 / 403(84 \%)$ \\
\hline LC168789 & Microdiplodia hawaiiensis & $\underline{\mathrm{JN} 198395}$ & $558 / 559(99 \%)$ \\
\hline LC168791 & Phoma herbarum & $\underline{\text { KP739881 }}$ & $519 / 523(99 \%)$ \\
\hline LC168792 & Phialemonium aff. Dimorphosporum & $\underline{\mathrm{AY} 188371}$ & $529 / 537(99 \%)$ \\
\hline LC168793 & Plenodomus sp. SC5S1-1 & $\underline{\text { KT235910 }}$ & $456 / 496(92 \%)$ \\
\hline LC168794 & Pseudocercospora sp. U02 & $\underline{\mathrm{JQ} 809678}$ & $512 / 515(99 \%)$ \\
\hline LC168795 & Stagonosporopsis cucurbitacearum & $\underline{\mathrm{AB} 266846}$ & $533 / 537(99 \%)$ \\
\hline LC168796 & Trichoderma koningiopsis & $\underline{\text { KP340235 }}$ & $568 / 568(100 \%)$ \\
\hline LC168787 & Fungal endophyte sp. JP33 & $\underline{\mathrm{AB} 255254}$ & $534 / 543(98 \%)$ \\
\hline LC168767 & Uncultured Basidiomycota clone R043SL3_C3 & $\underline{\mathrm{JX} 999054}$ & $558 / 562(99 \%)$ \\
\hline LC168790 & Peniophora incarnate & $\underline{\mathrm{KC} 820949}$ & $599 / 603(99 \%)$ \\
\hline
\end{tabular}

APPLIED ECOLOGY AND ENVIRONMENTAL RESEARCH 16(1):677-695.

http://www.aloki.hu • ISSN 15891623 (Print) • ISSN 17850037 (Online)

DOI: http://dx.doi.org/10.15666/aeer/1601_677695

(c) 2018, ALÖKI Kft., Budapest, Hungary 

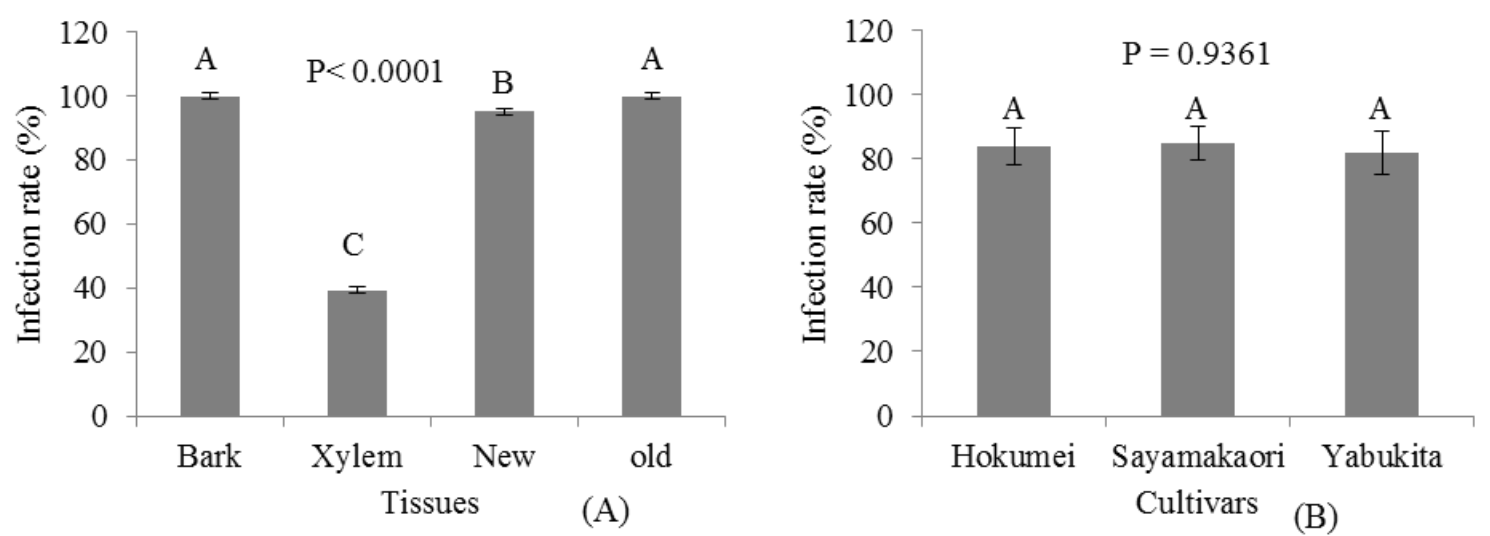

Figure 2. Comparison of mean infection rates among tissue types $(A)$ and cultivars $(B)$ by Tukey-Kramer test at the $\alpha=0.05$ level (different letters show significant differences among tested cultivars and tissue types). Error bars $=$ standard error $(S E)$

\section{Relative dominance}

A total of 520 isolates was obtained from 600 segments (Table 2), and classified by morphological and molecular analyses into 44 species and operational taxonomic units (OTUs; defined by DNA sequences, OTUs are regarded as 'species' below). Forty-one species $(93.2 \%)$ belonged to the phylum Ascomycota and two (4.5\%) to Basidiomycota; one species could not be identified and was named Fungal endophyte sp. Glomerellales was the predominant order and Diaporthales and Pleosporales were the most diverse orders. Seventeen species (38.6\%) belonged to Diaporthales and 10 species $(22.7 \%)$ to Pleosporales. Other species were from the orders Botryosphaeriales, Capnodiales, Hypocreales, Sordariales, Xylariales, and Russulales.

The RD ranged from 70.8 to $0.4 \%$. Colletotrichum gloeosporioides f. sp. camelliae and Pleosporales sp. predominated (70.8 and 52.3\%, respectively). Other species with a D > 1\% included $P$. glomerata, Botryosphaeria dothidea, Cladosporium asperulatum, Diaporthe eres, Alternaria mali, Guignardia mangiferae, Setophoma chromolaena, Diaporthe nobilis, Phomopsis spp., Acremonium strictum, Glomerella sp., uncultured Basidiomycota sp., and Pestalotiopsis sp. The 26 endophytes with a D of $<1 \%$ were regarded as rare species.

\section{Cultivar preference}

The CF (Table 2; Fig. 3) of the endophytic fungi differed significantly among the cultivars. The four most common endophytes, with the exception of Pleosporales sp., showed significant differences in host preference for $C$. gloeosporioides $\mathrm{f}$. $\mathrm{sp}$. camelliae, $P$. glomerata, and $B$. dothidea $(P=0.018,0.0004$, and 0.0251 , respectively). The predominant endophyte, $C$. gloeosporioides f. sp. Camelliae, was isolated from all cultivars but showed the lowest CF in Yabukita (22, 2, 6, and 48\% in bark, xylem, new leaf, and old leaf, respectively). The second most dominant endophyte, Pleosporales sp., colonized all cultivars equally. $P$. glomerata was also isolated from all cultivars but showed a CF of $2 \%$ in Hokumei bark and new leaf tissues. The fourth most dominant species, B. dothidea, was isolated from the cultivars Hokumei and Yabukita but not from Sayamakaori. 

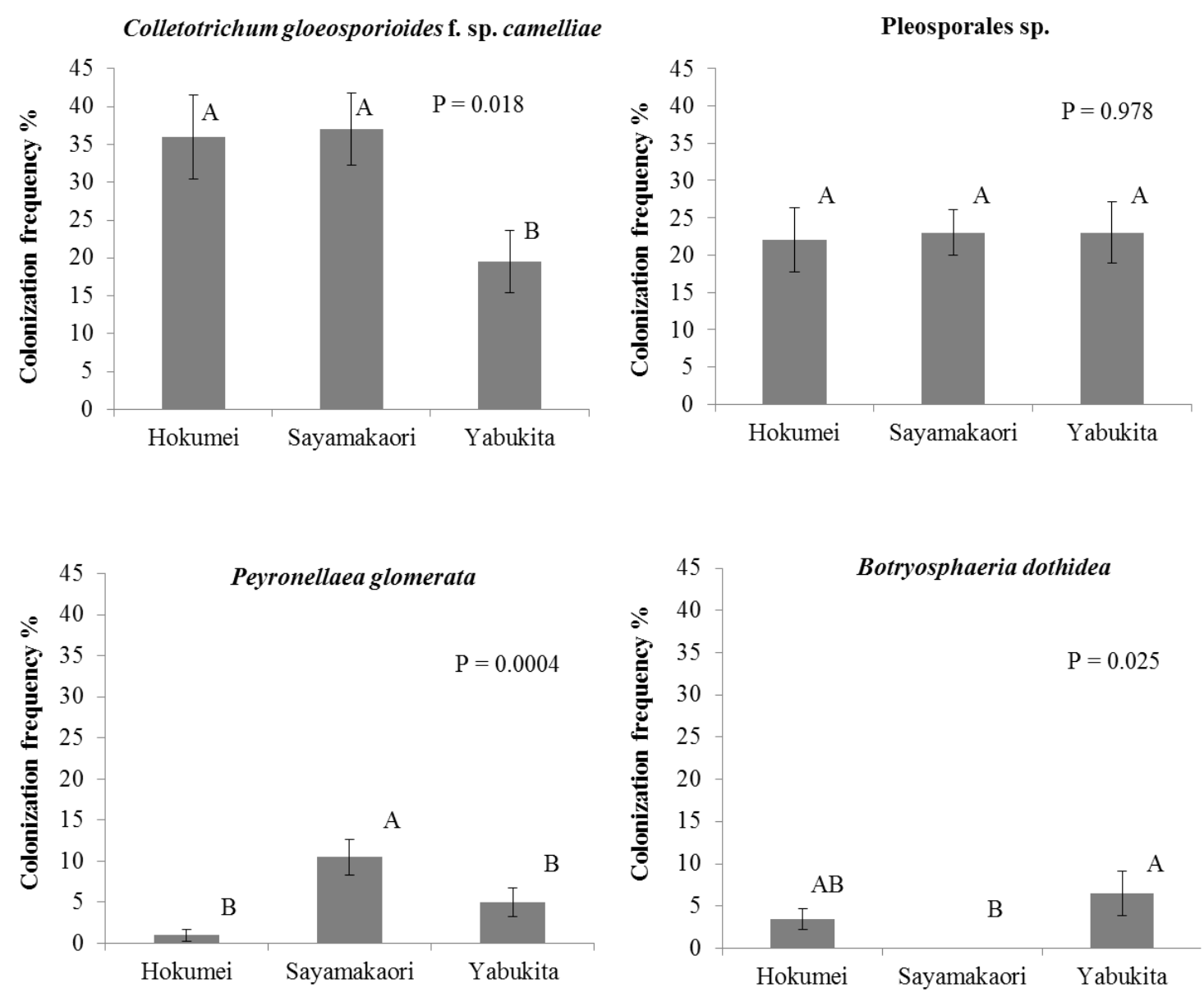

Figure 3. Mean CFs of four endophytic fungi with a $D>7 \%$ in three cultivars (different letters above columns indicate significant differences among cultivars). Tukey-Kramer HSD test, $\alpha=$ 0.05. Error bars $=S E$

\section{Tissue preference}

The CF of endophytes differed markedly among the tissue types (Table 2; Fig. 4). Most of the endophytes showed a strong tissue preference. The $\mathrm{CF}$ of $C$. gloeosporioides $\mathrm{f}$. sp. camelliae was significantly higher in bark and old leaf tissues than in new leaf and xylem tissues. Pleosporales sp. showed a significantly higher CF in new and old leaf tissues than stem tissues (bark and xylem); the highest CF was in new leaf tissues. The CF of Peyronellaea glomerata did not differ significantly among the tissues. Botryosphaeria dothidea showed the highest $\mathrm{CF}$ in bark tissues. G. mangiferae and Glomerella sp. were tissue-specific endophytes, as they were detected in only leaf and stem tissues, respectively. 

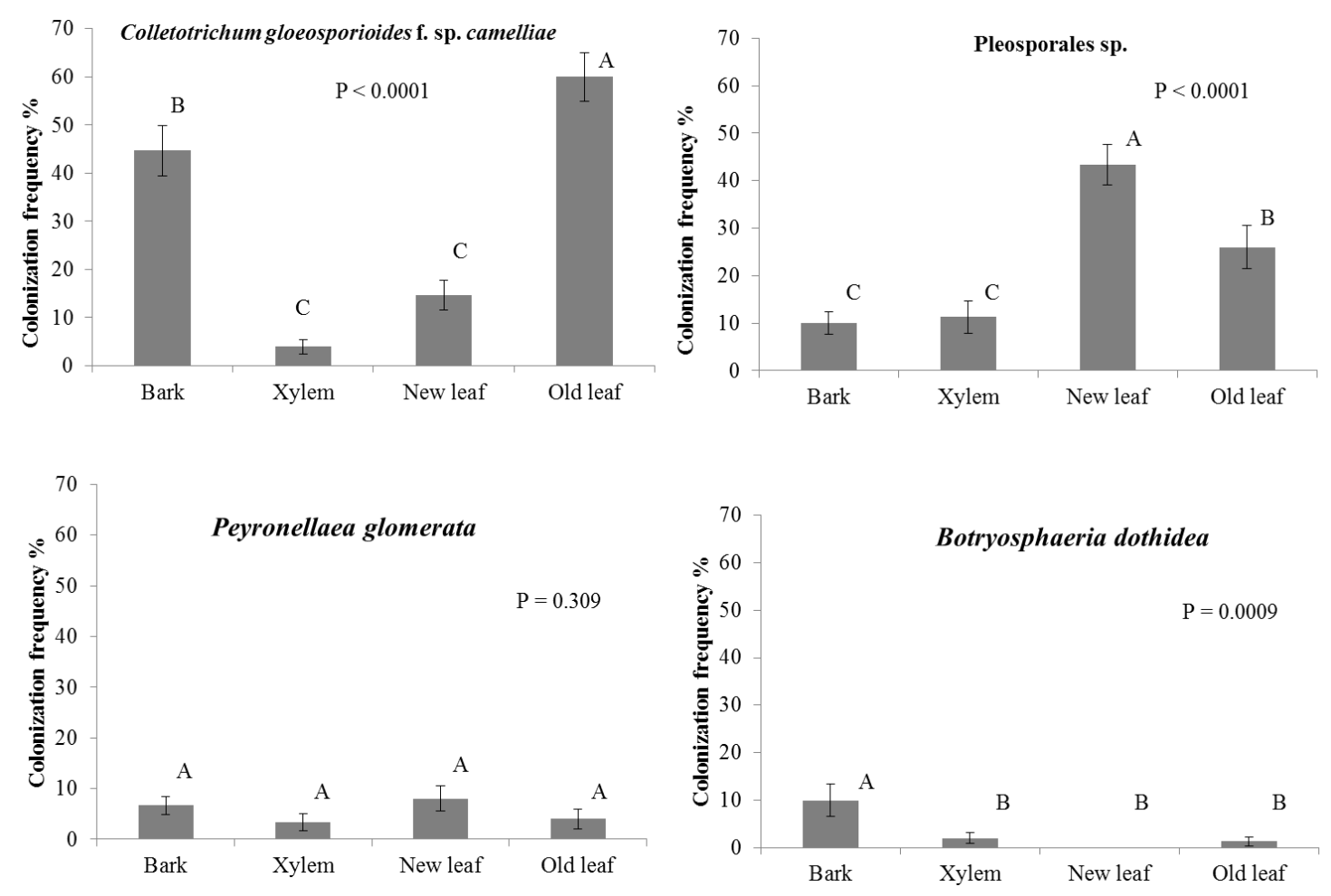

Figure 4. Mean CFs of four endophytic fungi with a D > 7\% among the tissue types (different letters above columns indicate significant differences. Tukey-Kramer HSD test, $\alpha=0.05$. Error

$$
\text { bars }=S E
$$

\section{Diversity and evenness of endophytic mycoflora}

The Shannon-Wiener diversity index $\left(\mathrm{H}^{\prime}\right)$ of endophytic fungi varied among the cultivars as well as the tissue types (Table 2). The values ranged from 2.48 in the bark of Yabukita to 0.79 in the old leaf of Hokumei. Among the tested tissues, old leaf tissues showed the lowest diversity indexes in all cultivars; 0.79, 1.23, and 1.54 in Hokumei, Sayamakaori, and Yabukita, respectively. New leaf tissues had a higher diversity index than old leaf tissues; 1.53, 2.01, and 1.93 in Hokumei, Sayamakaori, and Yabukita, respectively. Bark tissues exhibited the highest diversity index in Yabukita (2.48), followed by Hokumei (1.98) and Sayamakaori (1.51). Xylem tissues also showed high diversity indexes, with the highest in Hokumei (2.27) and the lowest in Yabukita (1.85). Among the tissues, the evenness index was highest in xylem in all cultivars $(0.71,0.8$, and 0.7 in Hokumei, Sayamakaori, and Yabukita, respectively).

The rarefaction curve for the endophytes indicated the highest species richness in bark tissues and the lowest in old leaf tissues (Fig. 5). Of 44 species, 24 were detected in bark, 19 in xylem, 20 in new leaf tissues, and 14 in old leaf tissues. Among the cultivars, Yabukita showed the highest species richness (29 species), followed by Hokumei (26) and Sayamakaori (24) (Fig. 5B). Both rarefaction curves were steep, indicating that more endophytic fungal species remain to be discovered in tea plants. 

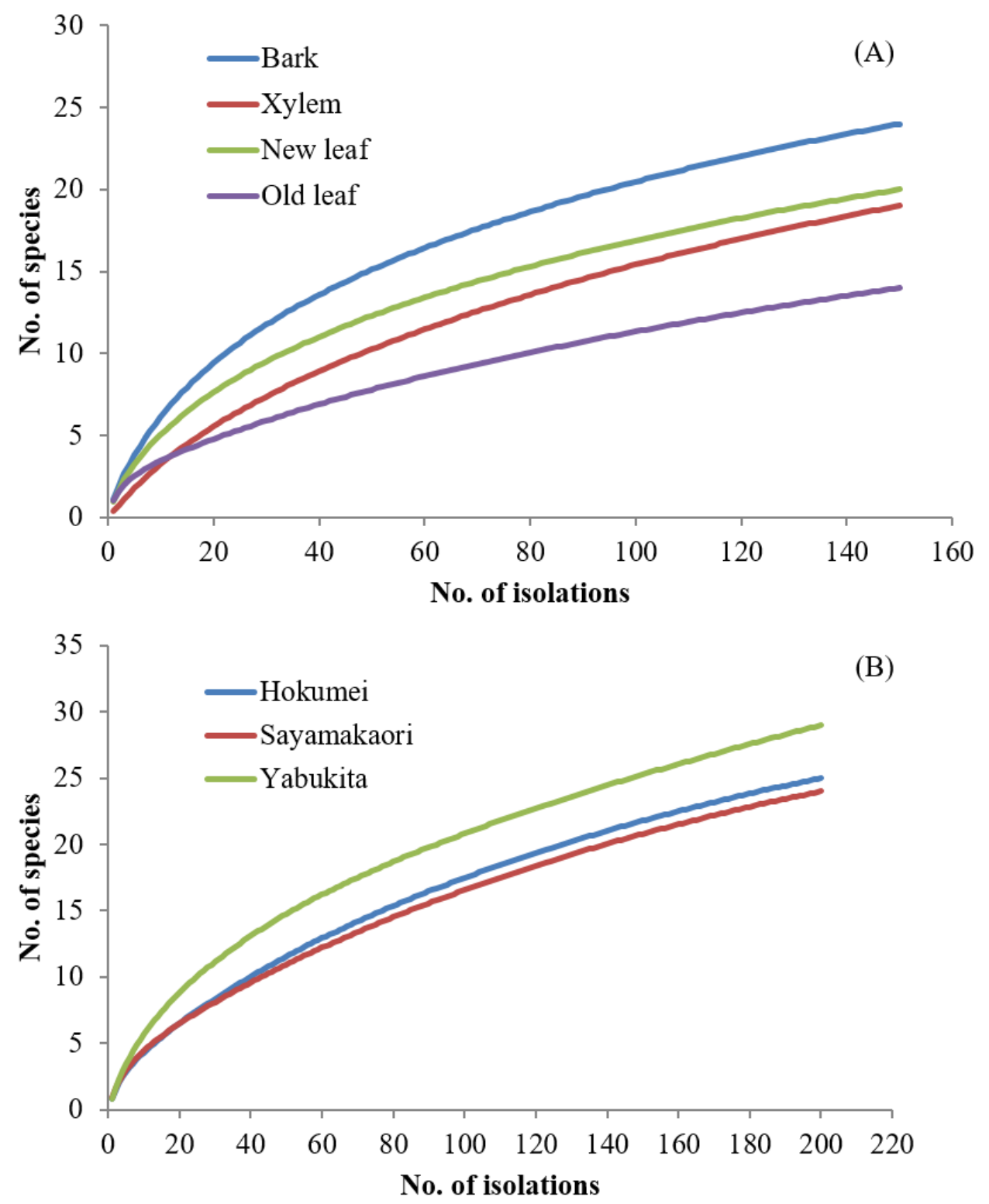

Figure 5. Rarefaction curves showing endophytic fungal species isolated from (A) different tissues and (B) cultivars

\section{Effect of cultivar and tissue on endophytic fungal community structure}

According to the PERMANOVA results, cultivar did not exert a significant effect on the tea endophytic fungal community structure $\left(P=0.0955 ; \mathrm{R}^{2}=0.13\right)$. In contrast, tissue type had a significant impact on fungal endophyte community structure $(P=$ $\left.0.0001 ; \mathrm{R}^{2}=0.66\right)$. The NMDS plot shows that the endophytic fungal community was similar among the cultivars but significantly different among the tissue types (Fig. 6 ). 


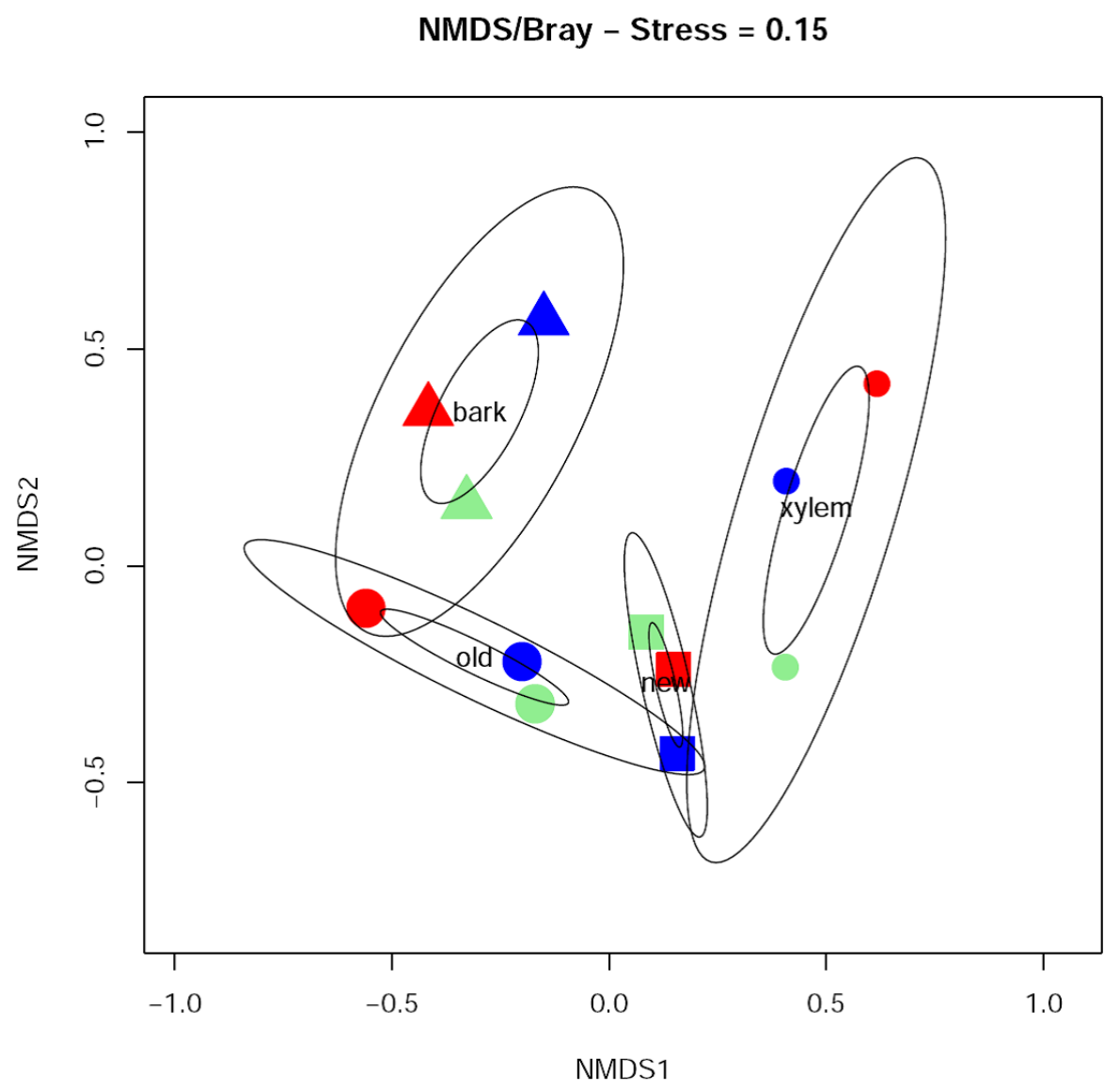

Figure 6. Non-metric multidimensional scaling (NMDS) plot of endophytic fungal communities $($ red $=$ Hokumei, green $=$ Sayamakaori, blue $=$ Yabukita $;$ triangle $=$ bark, square $=$ new leaf, small cycles $=$ xylem, large cycles $=$ old leaf). Cultivars: $R^{2}=0.13, P=0.0955$; tissues: $R^{2}=$ $0.66, P=0.0001 ;$ confidence level $=0.95$

\section{Discussion}

Most endophytic fungi in this study belonged to the phylum Ascomycota. Lu et al. (2007) reported a similar result in tea plants in southern Henan province, China. According to Rodriguez et al. (2009), endophytic fungi from woody plants are nonclavicipitaceous endophytes. They are highly diverse, and most belong to the phylum Ascomycota and a minority to Basidiomycota.

Diaporthales was the most diverse order in this study, of which the genera Phomopsis and Diaporthe predominated. These genera have a wide host range; conversely, the same plant can host several species of the Phomosis-Diaporthe complex (Rehner and Uecker, 1994; Van Niekerk et al., 2005).

The fungal endophytic community in this study was somewhat different from those in southern Henan Province ( $\mathrm{Lu}$ and Wu, 2006; Lu et al., 2007), Fujian Province (Chen 2007), and Zijin hill, Nanjing City, China (Fang et al., 2013). Three dominant endophytic fungi of tea plants, Neurospora and Rosellinia (Fang et al., 2013), and Chaetomium ( $\mathrm{Lu}$ and $\mathrm{Wu}, 2006$ ), were not detected in the present study. Therefore, the endophytic fungal community of tea plants varies according to geographical location.

The endophytic genus Colletotrichum reportedly predominates in tea plants (Lu et al., 2007; Fang et al., 2013). Colletotrichum endophytes of tea plants as well as other 
Camellia plants were identified only to the genus level by Liu et al. (2015), and tended to be regarded as host-specific endophytic fungi of Camellia plants. C. gloeosporioides f. sp. camelliaeas was also the predominant endophytic fungus in this study.

\section{Cultivar preference}

The IR did not differ significantly among the cultivars. The cultivars were grown at the same time in the same plot and were subjected to the same agricultural management practices. Although the tested cultivars have specific morphological and genetic characteristics, these differences did not affect the rate of infection by endophytic fungi; the average infection rate was $\sim 80 \%$. Such a high infection rate is likely because the study site is surrounded by tea plantations, which results in a dense inoculum.

The endophytes exhibited cultivar-specific colonization. According to Tian et al. (2004) and Naik et al. (2009), the fungal endophytic community can vary markedly among cultivars, and resistance to disease may be the major determinant of endophytic community structure. Leaf morphology and pigment content also affect endophytic community composition (Sanchez-Azofeifa et al., 2012). Endophyte richness is related to leaf traits such as water content, chlorophyll content, fresh:dry weight ratio, and polyphenol/leaf specific weight. The tested cultivars exhibited different morphological characteristics such as leaf color, shape, thickness and size, branching style, and resistance to disease. These factors could also be related to the differences in fungal composition and diversity among the cultivars.

\section{Tissue preference}

The IR differed significantly among the tissue types, likely due to differences in the nutrient content and anatomy of the tissues and the duration of aerial spore exposure. The lowest IR was in xylem tissues in all cultivars. The nutrient content of xylem tissues is lower than that of other tissues (Siebrecht et al., 2003; Yadeta and Thomma, 2014), which explains why few endophytes colonize this tissue. Xylem possesses highly structured and rigid secondary xylem walls and pit membranes with extremely small pores. The lignified walls of xylem tissue function as a structural barrier to colonization by endophytic fungi. Bark tissue showed a 100\% IR in all cultivars. Bark tissues are rich in sugars (Yadeta and Thomma, 2014), which favors colonization by an endophytic mycoflora. Tea plants are perennial and the outermost tissues are exposed to aerial spores of fungal endophytes for longer than xylem tissues. This may also explain the lower IR of new leaves compared with old leaves. Endophytes tend to be transmitted horizontally between woody plants (Fisher et al., 1993).

Most of the fungal species isolated in this study showed tissue specificity. Fisher and Petrini (1988) reported that the xylem-specific endophytes Phomopsis sp., Coniothyrium, and Coniochaeta were the predominant endophytes in the stem tissues of Ulex europaeus and Colletotrichum sp. In the present study, the predominant endophyte Colletotrichum sp. showed a high colonization frequency in bark and old leaf tissues; this is in agreement with the findings of Fang et al. (2013).

Pleosporales sp. was the second most frequently isolated endophyte and showed a strong preference for new leaf tissues. Pleosporales sp. was first reported as a tea endophyte with a preference for leaf tissues by Fang et al. (2013) in the tea plantations of Zijin hill of Nanjing City, China. This endophyte may have coevolved with tea plants 
and is a rare species. However, Pleosporales sp. was the second most dominant endophyte in this study.

G. magniferae also exhibited leaf specificity. G. magniferae is a sexual stage of Phyllosticta that is usually isolated as an endophyte and rarely as a plant pathogen that can infect 70 plant families (Wikee et al., 2013). Guignardia was isolated as an endophyte from tea plants (Fang et al., 2013), Quercus myrsinifolia (Matsumura and Fukuda, 2015), and Platycladus orientalis (Wijeratne et al., 2008).

Old leaf tissues showed the lowest diversity index in all cultivars, and new leaf tissues had a higher diversity index than old leaf tissues. According to Herre et al. (2007), the diversity of endophytic fungi usually declines as the leaves age, but the fungal density (infection rate) increases. The endophytic fungal community of old leaves was dominated by $C$. gloeosporioides f. sp. camelliae. Colletotrichum species are normally aggressive and fast-growing. Ding et al. (2007) reported that Colletotrichum can grow easily under various environmental conditions. The evenness index was highest in xylem tissues in all cultivars, which suggests that endophytes are distributed more evenly in xylem than in other tissues.

\section{Effect of cultivar and tissue type on endophytic community structure}

According to the PERMANOVA and NMDS results, tissue type exerted a greater effect on endophytic fungal community structure than did cultivars. Most of the predominant endophytes were isolated from at least two cultivars; no individual cultivar had a unique fungal community. The predominant endophytes belonged to the genera Colletotrichum, Phomopsis, Phoma, and Guignardia. These endophytes have a wide host range and can colonize several taxonomically unrelated plant hosts (Murali et al., 2006; Sieber, 2007). Moreover, the cultivars are closely genetically related; Sayamakaori and Hokumei are derived from Yabukita tea plants. The level of similarity of endophyte communities increases with increasing genetic relatedness of the host plants (Sieber 2007).

\section{Conclusion}

The composition and diversity of the endophytic fungal community of tea plants were affected by tissue type and cultivar. The predominant endophytes showed preferences for certain tissue types or cultivars. However, tissue type played a more important role in shaping endophytic fungal community structure than did cultivar. Few studies have evaluated the endophytic fungi of Japanese tea cultivars; this is to our knowledge the first report of the diversity of endophytic fungi in Japanese tea cultivars. These results will facilitate further research on the growth and development of tea plants and sustainable tea production.

Acknowledgments. This study was supported by the ADB-JSP scholarship program. We thank Mr. Atsushi Takahashi and the staff of Saitama Tea Research Institute for providing us with tea plant materials for this research.

Conflicts of Interest. The authors declare no conflicts of interest. All experiments undertaken in this study comply with the current laws of the country in which they were performed. 


\section{REFERENCES}

[1] Arnold, A. E., Lutzoni, F. (2007): Diversity and host range of foliar fungal endophytes: are tropical leaves biodiversity hotspots? - Ecology 88(3): 541-549.

[2] Caicedo, R. (2016): The Hokumei Tea Cultivar. (http://www.myjapanesegreentea.com/hokumei) Accessed 18 Jul 2016.

[3] Caicedo, R. (2016) The Sayamakaori Tea Cultivar. (http://www.myjapanesegreentea.com/sayamakaori) Accessed 18 Jul 2016.

[4] Campisano, A., Antonielli, L., Pancher, M., Yousaf, S., Pindo, M., Pertot, I. (2014): Bacterial endophytic communities in the grapevine depend on pest management. - PloS one 9(11): e112763.

[5] Chang, K. (2015): World tea production and trade: Current and future development. Food and Agriculture Organization of the United Nation. Rome.

[6] Chen, H.Q. (2007): A preliminary study on endophytic fungi in tea plant (Camellia sinensis). - Fuzhou: Fujian, Normal University, Beijing, China.

[7] Cheplick, G.P., Perera, A., Koulouris, K. (2000): Effect of drought on the growth of Lolium perenne genotypes with and without fungal endophytes. - Functional Ecology 14: $657-667$.

[8] Crane, J.H., Balerdi, C.F. (2013): Tea Growing in the Florida Home Landscape. University of Florida Publication \#HS1058, http://edis.ifas.ufl.edu/hs308

[9] Davey, M.L., Currah, R.S. (2006): Interactions between mosses (Bryophyta) and fungi. Botany 84: 1509-1519.

[10] Ding, Y., Chu, J.J., Gu, Z.F., Zhuang, Q. (2007): Effect of different factors on growth and spore production of a Colletotrichum sp., a potential biocontrol agent for water hyacinth. - Journal of Aquatic Plant Management 45: 129-131.

[11] Fang, W., Yang, L., Zhu, X., Zeng, L., Li, X. (2013): Seasonal and habitat dependent variations in culturable endophytes of Camellia sinensis. - Journal of Plant Pathology \& Microbiology 4:169. doi:10.4172/2157-7471.1000169

[12] Fisher, P.J., Petrini, O. (1988): Tissue specificity by fungi endophytic in Ulex europaeus. - Sydowia 40: 46-50.

[13] Fisher, P.J., Petrini, O., Sutton, B. C. (1993): A comparative study of fungal endophytes in leaves xylem and bark of Eucalyptus nitens in Australia and England. - Sydowia 45: $338-345$.

[14] Herre, E.A., Mejía, L.C., Kyllo, D.A., Rojas, E., Maynard, Z., Butler, A., Van Bael, S.A. (2007): Ecological implications of anti-pathogen effects of tropical fungal endophytes and mycorrhizae. - Ecology 88: 550-558.

[15] Izumitsu, K., Hatoh, K., Sumita, T., Kitade, Y., Morita, A., Gafur, A., Ohta, A., Kawai, M., Yamanaka, T., Neda, H., Ota, Y. (2012): Rapid and simple preparation of mushroom DNA directly from colonies and fruiting bodies for PCR. - Mycoscience 53: 396-401.

[16] Keith, L., Ko, W. H., \& Sato, D. M. (2006): Identification guide for diseases of tea (Camellia sinensis).

[17] Liu, F., Weir, B.S., Damm, U., Crous, P.W., Wang, Y., Liu, B., Wang, M., Zhang, M., Cai, L. (2015): Unravelling Colletotrichum species associated with Camellia: employing ApMat and GS loci to resolve species in the C. gloeosporioides complex. Persoonia: Molecular Phylogeny and Evolution of Fungi 35: 63.

[18] Lu, D., Wu, X. (2006): Fungal succession on tea leaves in the southern area of Henan province. - Journal of Nanjing Forestry University, Natural Sciences Edition, 2006-01.

[19] Lu, D.S., Wang, J.P., Wu, X.Q., Ye, J.R. (2007): The species and distribution of endophytic fungi in tea trees. - Journal of Henan Agricultural Sciences 10: 54-56.

[20] Ludwig, J.A., Reynolds, J.F. (1988): Statistical ecology: a primer in methods and computing (Vol. 1). - John Wiley \& Sons. 
[21] Matsumura, E., Fukuda, K. (2013): A comparison of fungal endophytic community diversity in tree leaves of rural and urban temperate forests of Kanto district, eastern Japan. - Fungal Biology 117: 191-201.

[22] Matsumura, E., Fukuda, K. (2015): Fungal endophytic communities in leaves of Quercus myrsinifolia and Eurya japonica - Their within-leaf distribution and antagonism. - Tree and Forest Health 19:195-204.

[23] Murali, T.S., Suryanarayanan, T.S., Geeta, R. (2006): Endophytic Phomopsis species: host range and implications for diversity estimates. - Canadian Journal of Microbiology 52: 673-680.

[24] Naik, B.S., Shashikala, J., Krishnamurthy, Y.L. (2009): Study on the diversity of endophytic communities from rice (Oryza sativa L.) and their antagonistic activities in vitro. - Microbiological Research 164: 290-296.

[25] Nalini, M.S., Sunayana, N., Prakash, H.S. (2014): Endophytic fungal diversity in medicinal plants of Western Ghats, India. - International Journal of Biodiversity, Article ID 494213.

[26] Nath, R., Sharma, G.D., Barooah, M. (2015): Plant growth promoting endophytic fungi isolated from tea (Camellia sinensis) shrubs of Assam, India. - Applied Ecology and Environmental Research 13: 877-891.

[27] Osono, T. (2014): Diversity and ecology of endophytic and epiphytic fungi of tree leaves in Japan: a review. - In: Advances in Endophytic Research. Springer, India. pp. 3-26. https://doi.org/10.1007/978-81-322-1575-2_1

[28] Petrini, O. (1991): Fungal endophytes of tree leaves. - In: Andrews, J. H., Hirano, S. S. (eds.) Microbial Ecology of Leaves. Springer, New York. pp. 179-197.

[29] Rabha, A.J., Naglot, A., Sharma, G.D., Gogoi, H.K., Veer, V. (2014): In vitro evaluation of antagonism of endophytic Colletotrichum gloeosporioides against potent fungal pathogens of Camellia sinensis. - Indian Journal of Microbiology 54: 302-309.

[30] Rehner, S.A., Uecker, F.A. (1994): Nuclear ribosomal internal transcribed spacer phylogeny and host diversity in the coelomycete Phomopsis. - Canadian Journal of Botany 72: 1666-1674.

[31] Rodriguez, R.J., White, Jr. J.F., Arnold, A.E., Redman, R.S. (2009): Fungal endophytes: diversity and functional roles. - New Phytologist 182: 314-330.

[32] Sanchez-Azofeifa, A., Oki, Y., Fernandes, G. W., Ball, R.A., Gamon, J. (2012): Relationships between endophyte diversity and leaf optical properties. - Trees 26: 291299.

[33] Sieber, T.N. (2007): Endophytic fungi in forest trees: are they mutualists? - Fungal Biology Reviews 21: 75-89.

[34] Siebrecht, S., Herdel, K., Schurr, U., Tischner, R. (2003): Nutrient translocation in the xylem of poplar - diurnal variations and spatial distribution along the shoot axis. - Planta 217: 783-793.

[35] Tian, X.L., Cao, L.X., Tan, H.M., Zeng, Q.G., Jia, Y.Y., Han, W.Q., Zhou, S.N. (2004): Study on the communities of endophytic fungi and endophytic actinomycetes from rice and their antipathogenic activities in vitro. - World Journal of Microbiology and Biotechnology 20: 303-309.

[36] Van Niekerk, J.M., Groenewald, J.Z., Farr, D.F., Fourie, P.H., Halleer, F., Crous, P.W. (2005): Reassessment of Phomopsis species on grapevines. - Australasian Plant Pathology 34: 27-39.

[37] White, T.J., Bruns, T., Lee, S.J.W.T., Taylor, J.W. (1990): Amplification and direct sequencing of fungal ribosomal RNA genes for phylogenetics. - PCR Protocols: a Guide to Methods and Applications 18: 315-322.

[38] Wijeratne, E.K., Paranagama, P.A., Marron, M.T., Gunatilaka, M.K., Arnold, A.E., Gunatilaka, A.L. (2008): Sesquiterpene quinones and related metabolites from Phyllosticta spinarum, a fungal strain endophytic in Platycladus orientalis of the Sonoran Desert (1). - Journal of Natural Products 71: 218-222. 
[39] Wikee, S., Lombard, L., Crous, P.W., Nakashima, C., Motohashi, K., Chukeatirote, E., McKenzie, E., Hyde, K.D. (2013): Phyllosticta capitalensis, a widespread endophyte of plants. - Fungal Diversity 60: 91-105.

[40] Yadeta, K.A., Thomma, B.P. (2014): The xylem as battleground for plant hosts and vascular wilt pathogens. - Induced Plant Responses to Microbes and Insects, 110.

[41] Yagi, C., Ikeda, N., Sato, D.M. (2010): Characteristics of eight Japanese tea cultivars. [Cooperative Extension Service], College of Tropical Agriculture and Human Resources, - University of Hawaii at Mānoa. 